\title{
Evaluation of diet in preschool-age children with Down syndrome - preliminary examination
}

\section{Ocena sposobu żywienia u dzieci z zespołem Downa w wieku przedszkolnym - badanie wstępne}

\author{
Anna Wrzochal', Aleksandra Gładyś-Jakubczyk², Edyta Suliga ${ }^{3}$ \\ 'Doctoral Studies, Faculty of Medicine and Health Sciences, Jan Kochanowski University, Kielce, Poland \\ Head of the Faculty: Prof. Marianna Janion MD, PhD \\ ${ }^{2}$ Neonatology Residency, Department of Neonatology, Provincial Hospital, Kielce, Poland \\ Head of the Department: Grażyna Pazera MD \\ ${ }^{3}$ Department of Nutrition and Dietetics, Institute of Public Health, Faculty of Medicine and Health Sciences, Jan Kochanowski \\ University, Kielce, Poland \\ Head of the Department: Prof. JKU Edyta Suliga
}

Key words: overweight, body mass index, Down syndrome, nutritional errors.

Słowa kluczowe: nadwaga, wskaźnik masy ciała, zespół Downa, błędy żywieniowe.

\begin{abstract}
Introduction: Down syndrome (DS) is the most common genetic pathology in the population. The risk factors of overweight and obesity in children with DS have not been comprehensively examined, and research in this area, conducted in Poland, is scarce.

Aim of the research: To evaluate the diets of children with Down syndrome in preschool age, depending on their nutritional status.

Material and methods: The survey was conducted in children with DS between the ages of three and six years. The analysis included 50 questionnaires correctly completed by parents or legal guardians. The children were divided into three groups according to the body mass index (BMI) index: overweight children, children with a normal BMI, and underweight children. To determine the relationship between BMI and diet, the $\chi^{2}$ test was used, and the significance level was $p<0.05$.

Results: Overweight children consume significantly more meals in kindergarten than other children $(p=0.04)$, including two lunches (in kindergarten and at home) $(p=0.02)$, and more often eat between meals $(p=0.007)$. In addition, hypothyroidism was significantly more frequent among children with overweight and obesity $(p=0.005)$. In the study group we also found frequent, unjustified applications of elimination diets, resulting from parents' conviction about their beneficial effects on the health of children with DS.

Conclusions: In preschool-age children with Down syndrome, numerous nutritional errors are made resulting in disturbances in their nutritional status. It seems necessary to introduce nutritional education that mainly covers kindergarten employees responsible for nutrition, as well as parents and guardians of children with Down syndrome.
\end{abstract}

\section{Streszczenie}

Wprowadzenie: Zespół Downa (ZD) to najczęściej występująca patologia genetyczna w populacji. Czynniki ryzyka wystąpienia nadwagi i otyłości u dzieci z ZD nie zostały dotąd wyczerpująco opisane, a badania w tym zakresie prowadzone w Polsce są nieliczne.

Cel pracy: Ocena sposobu żywienia dzieci z ZD w wieku przedszkolnym w zależności od stanu ich odżywienia.

Materiał i metody: Badanie ankietowe przeprowadzono u dzieci z ZD w wieku od 3 do 6 lat. Analizie poddano 50 kwestionariuszy prawidłowo wypełnionych przez rodziców lub opiekunów dzieci. Na podstawie wskaźnika masy ciała (BMI) podzielono dzieci na trzy grupy: dzieci z nadwagą, z prawidłowym BMI oraz z niedowagą. Do określenia zależności między BMI a sposobem żywienia zastosowano test $\chi^{2}$, przyjęto poziom istotności $p<0,05$.

Wyniki: Dzieci z nadwagą spożywały w przedszkolu istotnie więcej posiłków niż pozostałe dzieci $(p=0,04)$, jadły dwa obiady (w przedszkolu i w domu) $(p=0,02)$, a także częściej podjadały między posiłkami $(p=0,007)$. Dodatkowo wśród dzieci z nadwagą i otyłością istotnie częściej występowała niedoczynność tarczycy $(p=0,005)$. W badanej grupie stwierdzono też częste, nieuzasadnione stosowanie diet eliminacyjnych, wynikające z przekonania rodziców o ich korzystnym wpływie na zdrowie dziecka z ZD 
Wnioski: U dzieci z ZD w wieku przedszkolnym popełniane sa liczne błędy żywieniowe skutkujace zaburzeniami w stanie odżywienia. Konieczne wydaje się wprowadzenie edukacji żywieniowej obejmującej przede wszystkim pracowników przedszkoli odpowiedzialnych za żywienie oraz rodziców i opiekunów dzieci z ZD.

\section{Introduction}

Down syndrome (DS) is a well-recognised and researched chromosomal mutation associated with the tripling of genetic material on the $21^{\text {st }}$ chromosome. This is the most common genetic pathology in the population. It is estimated that it occurs in 6.1 to 13.1 out of 10,000 people $[1,2]$. This overexpression of genetic material is associated with the occurrence of dysmorphic features (including narrow and slanting eyes, small and flat nose, and poor growth), multilevel body disorders, mental retardation, physical and psychomotor delay, and many diet-related illnesses [3].

In people with DS, the following defects and illnesses occur more often than in the general population: congenital heart defects, digestive tract, urogenital, muscular, and osteoarticular defects as well as haematopoietic system disorders, impaired immune responses, visual defects, hypoacusia, epilepsy [3], endocrine disorders of the thyroid [4], and oral and dental diseases [5]. In patients with DS intolerance of food, malabsorption, metabolic disorders, as well as deficiencies of vitamins and minerals appear more frequently than in people without DS $[6,7]$.

The somatic development of children with DS is delayed and discordant from birth. In children with DS there is often a lower birth weight than in children without DS. According to the available data, it can be stated that in the first stage of life, a deficiency of body mass is observed in young children with DS, whereas overweight and obesity is observed in adolescence $[8,9]$. Among the reasons for this occurrence are metabolic disorders, abnormal blood leptin levels, and comorbidities, such as hypothyroidism $[4,10,11]$. However, it is worth paying attention not only to genetic conditions, but also to environmental factors, bad eating habits, and too little physical activity of children with DS [4]. Available data show that children with DS prefer eating food rich in simple carbohydrates that are easy to chew and swallow. Their diet is low in fresh vegetables and fruit, which leads to many nutritional deficiencies - vitamins, minerals, and fibre $[6,12]$. The nutritional behaviour of parents also contributes to the development of overweight and obesity in children with DS. Parents' nutritional behaviours are negatively influenced by factors such as the child's diagnosis, family income, age of the parent, and anxiety associated with the incorrect weight of the child. As a form of reward or consolation, parents often give children high-calorie and highly processed snacks abounding, among others, in sugar. Nutritional mistakes may also be caused by numerous dysfunctions related to disturbances of sucking, swallowing, hunger, and the functioning of many organs as well as intolerances and deficiencies accompanying people with DS, while these people and/or their relatives lack knowledge about optimal nutrition [13, 14].

The low level of physical activity may contribute to the development of overweight and obesity, which in children with DS may be associated with their poor physical fitness resulting from the associated defects of the musculoskeletal system and dysfunction of the muscular and osteoarticular system. In children with DS, hypotonia and laxity of the ligament-joint system often occur, which leads to dysfunctions and postural defects, abnormal curvatures of the spine, and chest deformities $[15,16]$. There is also social stigmatisation and a reluctance to undertake physical activity [17].

The risk factors of overweight and obesity in children with DS have not been comprehensively examined, and research in this area, conducted in Poland, is scarce.

\section{Aim of the research}

The aim of the study was to assess the diets of children with Down syndrome at preschool age, depending on their nutritional status.

\section{Material and methods}

A questionnaire was used, which involved preschool-age children with DS from 3 to 6 years old. There were 61 questionnaires, of which 11 were rejected due to the lack of complete data or because the age of the children was not in accordance with the guidelines of the study. In further analysis, 50 questionnaires were used. Questionnaires were completed by parents or legal guardians of the children. Before starting the tests, the parents or guardians of each child agreed to participation in the study. The approval of the Bioethics Committee of the Faculty of Medicine and Health Sciences of Jan Kochanowski University in Kielce No. 47/2018 was also obtained for the test.

The research used the authors' original questionnaire, consisting of 29 questions. The questionnaire contained questions on the child's diet up to 6 months of age and from 6 to 12 months of age, as well as the type of elimination diet used, concomitant birth defects and diseases, regularity of meals, snacking, meals in kindergarten, the frequency of consumption of selected groups of food products, liquids drunk, and information about which sources they use to learn about proper nutrition. The questionnaire also included questions about the child's basic anthropometric data (height and body mass). Parents were 
Table 1. Characteristics of the study group

\begin{tabular}{|lc|}
\hline Characteristics of the study group & $\mathrm{X} \pm$ SD; $\boldsymbol{N}(\%)$ \\
Age [years] & $4.52 \pm 1.1$ \\
Body mass $[\mathrm{kg}]$ & $16.74 \pm 4.06$ \\
Height $[\mathrm{m}]$ & $1.02 \pm 0.09$ \\
BMI $\left[\mathrm{kg} / \mathrm{m}^{2}\right]$ & $16.03 \pm 2.23$ \\
Congenital defect of the heart & $21(51.2)$ \\
$\begin{array}{l}\text { Congenital defects of the } \\
\text { gastrointestinal tract }\end{array}$ & $5(12.2)$ \\
Hypothyroidism & $27(65.9)$ \\
Other birth defects and/or diseases & $10(24.4)$ \\
\hline
\end{tabular}

asked to obtain these data from the children's health books. In the absence of current data, parents had to measure and weigh the child.

A preliminary examination will allow us to complete and refine this tool for further research. The author's original questionnaire was used for the study, because currently there is no validated Polish tool intended for this age group.

The values of anthropometric measurements height and body mass - were used to assess the nutritional status of the subjects of the study. On their basis, the body mass index (BMI) was calculated, which was compared to the developmental norms of children and adolescents aged $0-18$ years [18].

\section{Statistical analysis}

The obtained results were statistically analysed in the Statistica 13.1 program by StatSoft. Nutrition was evaluated in three groups: overweight children (BMI $>90^{\text {th }}$ centile), children with a normal BMI $\left(10^{\text {th }}-90^{\text {th }}\right.$ centile), and underweight children (BMI $<10^{\text {th }}$ centile). To determine the relationship between BMI and diet, the $\chi^{2}$ test was used, and the significance level was $<0.05$.

\section{Results}

The study covered a group of 50 children $-30 \%$ girls and $70 \%$ boys - aged $4.52 \pm 1.1$ years (Table 1 ). The mean BMI value of the study group, calculated on the basis of anthropometric data (body mass and height) given in the survey, was $16.03 \pm 2.23 \mathrm{~kg} / \mathrm{m}^{2}$. More than half of the subjects (52\%) had a normal body weight, $24 \%$ of the them had excessively low BMI, and the same amount (24\%) had overweight and obesity.

Birth defects and/or diseases occurred in $82 \%$ of children with DS. In $65.9 \%$ hypothyroidism was diagnosed. $51.2 \%$ of parents declared a congenital defect of the heart. Congenital defects of the gastrointestinal tract were found in $12.2 \%$ of the children, among them Hirschsprung's disease was most frequently mentioned. Hypothyroidism was significantly more common $\left(\chi^{2}=10.73, p=0.005\right)$ in overweight children (in 50\%) than in underweight ones (8.3\%).

Up to 6 months of age, $40 \%$ of the examined children were exclusively breastfed (Table 2). Every third child was mixed fed (breast and formula), 22\% were breastfed from 6 to 12 months of age, and the same number of children were mixed fed. No significant relationship was found between the way the baby was fed in the first year of life and his/her BMI in preschool age.

An elimination diet was used in 34\% of children. The parents most often declared a dairy-free, lactosefree, or gluten-free diet, and a diet with the restriction of easily digestible carbohydrates, which in the questionnaire was referred to as "diabetic" (Table 3). The subjects also eliminated single food products such as vegetables, fruit, or goat's milk. No relationship between the elimination diet and the BMI of the children was observed $\left(\chi^{2}=0.67, p=0.72\right)$.

As a reason for the elimination diet, more than half of the parents reported available information about the benefits of using it (Table 4). Almost every third child had lactose intolerance, and every fourth had a cow's milk protein allergy. One child was suffering from celiac disease. None of the parents of the children indicated that they suffered from diabetes.

Table 2. Feeding practices in the first year of the child's life

\begin{tabular}{|c|c|c|c|c|c|c|c|c|c|c|c|c|c|c|c|c|}
\hline \multirow{4}{*}{$\begin{array}{l}\text { Feeding } \\
\text { practices }\end{array}$} & \multicolumn{16}{|c|}{ Feeding period } \\
\hline & \multicolumn{8}{|c|}{ Up to 6 months } & \multicolumn{8}{|c|}{ From 6 to 12 months of age } \\
\hline & \multicolumn{2}{|c|}{$\begin{array}{l}\text { Under- } \\
\text { weight }\end{array}$} & \multicolumn{2}{|c|}{$\begin{array}{c}\text { Normal } \\
\text { BMI }\end{array}$} & \multicolumn{2}{|c|}{$\begin{array}{c}\text { Over- } \\
\text { weight }\end{array}$} & \multicolumn{2}{|c|}{ Total } & \multicolumn{2}{|c|}{$\begin{array}{l}\text { Under- } \\
\text { weight }\end{array}$} & \multicolumn{2}{|c|}{$\begin{array}{c}\text { Normal } \\
\text { BMI }\end{array}$} & \multicolumn{2}{|c|}{$\begin{array}{c}\text { Over- } \\
\text { weight }\end{array}$} & \multicolumn{2}{|c|}{ Total } \\
\hline & $N$ & $\%$ & $N$ & $\%$ & $N$ & $\%$ & $N$ & $\%$ & $N$ & $\%$ & $N$ & $\%$ & $N$ & $\%$ & $N$ & $\%$ \\
\hline Breastfed & 5 & 41.7 & 9 & 34.6 & 5 & 41.7 & 20 & 40 & 4 & 33.3 & 4 & 15.4 & 3 & 25 & 11 & 22 \\
\hline Mixed fed & 5 & 41.7 & 7 & 26.9 & 6 & 50 & 17 & 34 & 1 & 8.3 & 6 & 23.1 & 4 & 33.3 & 11 & 22 \\
\hline Formula & 2 & 16.6 & 10 & 38.5 & 1 & 8.3 & 13 & 26 & 7 & 58.4 & 16 & 61.5 & 5 & 41.7 & 28 & 56 \\
\hline$\chi^{2}, p$ & & & & 4.91, & 297 & & & & & & & 3.59, & .464 & & & \\
\hline
\end{tabular}


Table 3. Types of elimination diets used

\begin{tabular}{|lccccccccc|}
\hline \multirow{2}{*}{ Types of elimination diets } & \multicolumn{2}{c}{ Underweight } & \multicolumn{2}{c}{ Normal BMI } & \multicolumn{2}{c|}{ Overweight } & \multicolumn{2}{c|}{ Total } \\
\cline { 2 - 10 } & $\boldsymbol{N}$ & $\%$ & $\boldsymbol{N}$ & $\%$ & $\boldsymbol{N}$ & $\%$ & $\boldsymbol{N}$ & $\%$ \\
Dairy-free diet & 3 & 75 & 6 & 60 & 2 & 66.7 & 11 & 64.7 \\
Lactose-free diet & 1 & 25 & 6 & 60 & 3 & 100 & 10 & 58.8 \\
Gluten-free diet & 1 & 25 & 6 & 60 & 2 & 66.7 & 9 & 52.9 \\
$\begin{array}{l}\text { Diet with the restriction of easily digestible } \\
\text { carbohydrates }\end{array}$ & 1 & 25 & 5 & 50 & 1 & 33.3 & 7 & 41.2 \\
Other diets & 0 & 0 & 1 & 10 & 0 & 0 & 1 & 5.9 \\
\hline
\end{tabular}

Table 4. Reasons for the elimination diet

\begin{tabular}{|lccccccccc|}
\hline Reasons for the elimination diet & \multicolumn{3}{c}{ Underweight } & \multicolumn{2}{c}{ Normal BMI } & \multicolumn{2}{c}{ Overweight } & \multicolumn{2}{c|}{ Total } \\
\cline { 2 - 10 } & $\boldsymbol{N}$ & $\%$ & $\boldsymbol{N}$ & $\%$ & $\boldsymbol{N}$ & $\%$ & $\boldsymbol{N}$ & $\%$ \\
Available information about the benefits of using it & 2 & 50 & 5 & 50 & 2 & 66.7 & 9 & 52.9 \\
Lactose intolerance & 1 & 25 & 3 & 30 & 1 & 33.3 & 5 & 29.5 \\
Cow's milk protein allergy & 1 & 25 & 2 & 20 & 1 & 33.3 & 4 & 23.5 \\
Celiac disease & 0 & 0 & 1 & 10 & 0 & 0 & 1 & 5.9 \\
Diabetes & 0 & 0 & 0 & 0 & 0 & 0 & 0 & 0.0 \\
Other reasons & 1 & 25 & 3 & 30 & 0 & 0 & 4 & 23.6 \\
\hline
\end{tabular}

Among other reasons, the respondents mentioned the child's reluctance to eat certain groups of products, intestinal problems, excessive growth of Candida albicans fungus, and an attempt to maintain the child's slim figure.

The examined children with DS consumed an average of $4.86 \pm 0.45$ meals a day. Most of them, as many as $78 \%$ of the children, consumed five meals a day, $18 \%$ of children four meals a day, and $4 \%$ of children six or more meals a day. Body mass index was not associated with the number of meals consumed $\left(\chi^{2}=3.44, p=0.49\right)$.

The vast majority of the children (92\%) attended kindergarten. Parents declared that $10.9 \%$ of children consumed one meal a day in the kindergarten, $43.5 \%$ of children consumed two meals a day, $30.4 \%$ children three meals a day, and $15.2 \%$ children four meals. Of the children attending kindergarten, 71.7\% consumed breakfast before going to kindergarten, and $60.9 \%$ ate lunch with their family members, after returning home, despite eating lunch in kindergarten. There were statistically significant differences in the nutritional status of the subjects of the study, depending on the number of meals consumed in kindergarten $\left(\chi^{2}=13.31, p=0.04\right)$. As many as $60 \%$ of overweight children attending kindergarten ate three or four meals in kindergarten. For comparison, in a group excluding overweight children, 38.9\% of children consumed this number of meals. It was also found that $80 \%$ of overweight children attending kin- dergarten ate two lunches a day: one in kindergarten, the other at home. Among other children, the intake of two lunches was $55.6 \%\left(\chi^{2}=7.79, p=0.02\right)$. However, no significant relationship was found between breakfast consumption before going to kindergarten and the BMI of the children.

There were statistically significant relationships between the nutritional status of the subjects (BMI) and snacking $\left(\chi^{2}=21.05, p=0.007\right)$ (Table 5). Every day, as many as $25 \%$ of overweight children were found to snack, while $41.7 \%$ of underweight children never or almost never snacked.

The children most often snacked on fruit including juices, yoghurts and/or flavoured cheeses (Table 6). Slightly less frequent were salty snacks, sweets, junk food, and vegetables.

Most of the subjects consumed fruit and vegetables 1-2 times a day (Table 7).

Of the other product groups, children with DS consumed most often cereal products as well as meat and meat products (Table 8 ). There were no significant correlations between the frequency of consumption of any of the included product groups and the BMI of the children.

The beverages most frequently drunk by the children were water (44\%) and fruit juices (36\%).

Almost half of the parents or guardians completing the questionnaires (44\%) declared that they gained information about nutrition from the Internet, and only every fourth parent or guardian (24\%) in- 
Table 5. The frequency of snacking between meals

\begin{tabular}{|lcccccccc|}
\hline Frequency of snacking & \multicolumn{2}{c}{ Underweight } & \multicolumn{2}{c}{ Normal BMI } & \multicolumn{2}{c|}{ Overweight } & \multicolumn{2}{c|}{ Total } \\
\cline { 2 - 9 } & $\boldsymbol{N}$ & $\%$ & $\boldsymbol{N}$ & $\%$ & $\boldsymbol{N}$ & $\%$ & $\boldsymbol{N}$ & $\%$ \\
Never or almost never & 5 & 41.7 & 4 & 15.4 & 0 & 0 & 9 & 18 \\
$\begin{array}{l}\text { Once a month or less } \\
\text { frequently }\end{array}$ & 3 & 25 & 1 & 3.9 & 0 & 0 & 4 & 8 \\
Several times a month & 1 & 8.3 & 5 & 19.2 & 5 & 41.7 & 11 & 22 \\
Several times a week & 3 & 25 & 5 & 19.2 & 4 & 33.3 & 12 & 24 \\
Every day & 0 & 0 & 11 & 42.3 & 3 & 25 & 14 & 28 \\
Several times a day & 0 & 0 & 0 & 0 & 0 & 0 & 0 & 0 \\
$\chi^{2}, p$ & & & & $21.05,0.007$ & & & 0 \\
\hline
\end{tabular}

Table 6. Products eaten between meals

\begin{tabular}{|lcccccccc|}
\hline Products eaten between meals & \multicolumn{3}{c}{ Underweight } & \multicolumn{2}{c}{ Normal BMI } & \multicolumn{2}{c|}{ Overweight } & \multicolumn{2}{c|}{ Total } \\
\cline { 2 - 10 } & $\boldsymbol{N}$ & $\%$ & $\boldsymbol{N}$ & $\%$ & $\boldsymbol{N}$ & $\%$ & $\boldsymbol{N}$ & $\%$ \\
Fruit (including juices) & 4 & 33.2 & 11 & 42.3 & 3 & 25 & 18 & 36 \\
Yoghurt or flavoured cheese for snacking & 2 & 16.7 & 4 & 15.4 & 5 & 41.7 & 11 & 22 \\
Salty snacks & 2 & 16.7 & 3 & 11.5 & 2 & 16.7 & 7 & 14 \\
Sweets & 2 & 16.7 & 2 & 7.7 & 1 & 8.3 & 5 & 10 \\
Junk food & 0 & 0 & 1 & 3.9 & 0 & 0 & 1 & 2 \\
Vegetables & 0 & 0 & 0 & 0 & 1 & 8.3 & 1 & 2 \\
Other products & 2 & 16.7 & 5 & 19.2 & 0 & 0 & 7 & 14 \\
\hline
\end{tabular}

Table 7. The frequency of vegetable and fruit consumption

\begin{tabular}{|c|c|c|c|c|c|c|c|c|c|}
\hline \multirow[t]{2}{*}{ Products } & \multirow{2}{*}{$\begin{array}{c}\text { Frequency } \\
\text { of consumption }\end{array}$} & \multicolumn{2}{|c|}{ Underweight } & \multicolumn{2}{|c|}{ Normal BMI } & \multicolumn{2}{|c|}{ Overweight } & \multicolumn{2}{|c|}{ Total } \\
\hline & & $N$ & $\%$ & $N$ & $\%$ & $N$ & $\%$ & $N$ & $\%$ \\
\hline \multirow[t]{7}{*}{ Vegetables } & Never or almost never & 2 & 16.7 & 2 & 7.7 & 0 & 0 & 4 & 8 \\
\hline & Several times a month & 0 & 0 & 0 & 0 & 1 & 8.3 & 1 & 2 \\
\hline & Several times a week & 2 & 16.7 & 5 & 19.2 & 2 & 16.7 & 9 & 18 \\
\hline & 1-2 times a day & 7 & 58.3 & 17 & 65.3 & 7 & 58.3 & 31 & 62 \\
\hline & 3-4 times a day & 1 & 8.3 & 1 & 3.9 & 2 & 16.7 & 4 & 8 \\
\hline & 5 or more times a day & 0 & 0 & 1 & 3.9 & 0 & 0 & 1 & 2 \\
\hline & $\chi^{2}, p$ & \multicolumn{8}{|c|}{$8.01,0.628$} \\
\hline \multirow[t]{7}{*}{ Fruit } & Never or almost never & 1 & 8.3 & 1 & 3.9 & 0 & 0 & 2 & 4 \\
\hline & Several times a month & 0 & 0 & 1 & 3.9 & 1 & 8.3 & 2 & 4 \\
\hline & Several times a week & 4 & 33.4 & 4 & 15.4 & 2 & 16.7 & 10 & 20 \\
\hline & 1-2 times a day & 7 & 58.3 & 19 & 72.9 & 7 & 58.3 & 33 & 66 \\
\hline & 3-4 times a day & 0 & 0 & 1 & 3.9 & 2 & 16.7 & 3 & 6 \\
\hline & 5 or more times a day & 0 & 0 & 0 & 0 & 0 & 0 & 0 & 0 \\
\hline & $\chi^{2}, p$ & \multicolumn{8}{|c|}{$7.11,0.525$} \\
\hline
\end{tabular}


Table 8. The frequency of consumption of selected groups of food products

\begin{tabular}{|c|c|c|c|c|c|c|c|c|c|}
\hline \multirow[t]{2}{*}{ Products } & \multirow[t]{2}{*}{ Frequency of consumption } & \multicolumn{2}{|c|}{ Underweight } & \multicolumn{2}{|c|}{ Normal BMI } & \multicolumn{2}{|c|}{ Overweight } & \multicolumn{2}{|c|}{ Total } \\
\hline & & $N$ & $\%$ & $N$ & $\%$ & $N$ & $\%$ & $N$ & $\%$ \\
\hline \multirow{7}{*}{$\begin{array}{l}\text { Meat } \\
\text { and meat } \\
\text { products }\end{array}$} & Never or almost never & 0 & 0 & 0 & 0 & 0 & 0 & 0 & 0 \\
\hline & Once a month or less frequently & 0 & 0 & 2 & 7.7 & 0 & 0 & 2 & 4 \\
\hline & Several times a month & 0 & 0 & 0 & 0 & 1 & 8.3 & 1 & 2 \\
\hline & Several times a week & 7 & 58.3 & 15 & 57.7 & 8 & 66.7 & 30 & 60 \\
\hline & Every day & 5 & 41.7 & 9 & 34.6 & 3 & 25 & 17 & 34 \\
\hline & Several times a day & 0 & 0 & 0 & 0 & 0 & 0 & 0 & 0 \\
\hline & $\chi^{2}, p$ & \multicolumn{8}{|c|}{$5.63,0.466$} \\
\hline \multirow[t]{7}{*}{ Fish } & Never or almost never & 1 & 8.3 & 3 & 11.5 & 0 & 0 & 4 & 8 \\
\hline & Once a month or less frequently & 1 & 8.3 & 4 & 15.4 & 1 & 8.3 & 6 & 12 \\
\hline & Several times a month & 7 & 58.4 & 13 & 50 & 11 & 91.7 & 31 & 62 \\
\hline & Several times a week & 3 & 25 & 6 & 23.1 & 0 & 0 & 9 & 18 \\
\hline & Every day & 0 & 0 & 0 & 0 & 0 & 0 & 0 & 0 \\
\hline & Several times a day & 0 & 0 & 0 & 0 & 0 & 0 & 0 & 0 \\
\hline & $\chi^{2}, p$ & \multicolumn{8}{|c|}{$7.08,0.629$} \\
\hline \multirow{7}{*}{$\begin{array}{l}\text { Milk and } \\
\text { dairy } \\
\text { products }\end{array}$} & Never or almost never & 3 & 25 & 9 & 34.6 & 3 & 25 & 15 & 30 \\
\hline & Once a month or less frequently & 1 & 8.3 & 1 & 3.9 & 0 & 0 & 2 & 4 \\
\hline & Several times a month & 1 & 8.3 & 2 & 7.7 & 1 & 8.3 & 4 & 8 \\
\hline & Several times a week & 2 & 16.7 & 7 & 26.8 & 3 & 25 & 12 & 24 \\
\hline & Every day & 5 & 41.7 & 6 & 23.1 & 5 & 41.7 & 16 & 32 \\
\hline & Several times a day & 0 & 0 & 1 & 3.9 & 0 & 0 & 1 & 2 \\
\hline & $\chi^{2}, p$ & \multicolumn{8}{|c|}{$4.07,0.944$} \\
\hline \multirow[t]{7}{*}{ Eggs } & Never or almost never & 2 & 16.7 & 3 & 11.5 & 0 & 0 & 5 & 10 \\
\hline & Once a month or less frequently & 1 & 8.3 & 2 & 7.7 & 1 & 8.3 & 4 & 8 \\
\hline & Several times a month & 5 & 41.7 & 11 & 42.3 & 6 & 50 & 22 & 44 \\
\hline & Several times a week & 4 & 33.3 & 8 & 30.8 & 5 & 41.7 & 17 & 34 \\
\hline & Every day & 0 & 0 & 2 & 7.7 & 0 & 0 & 2 & 4 \\
\hline & Several times a day & 0 & 0 & 0 & 0 & 0 & 0 & 0 & 0 \\
\hline & $\chi^{2}, p$ & \multicolumn{8}{|c|}{$4.07,0.851$} \\
\hline \multirow[t]{7}{*}{ Animal fats } & Never or almost never & 3 & 25 & 6 & 23.1 & 3 & 25 & 12 & 24 \\
\hline & Once a month or less frequently & 3 & 25 & 2 & 7.7 & 1 & 8.3 & 6 & 12 \\
\hline & Several times a month & 0 & 0 & 4 & 15.4 & 2 & 16.7 & 6 & 12 \\
\hline & Several times a week & 4 & 33.3 & 6 & 23.1 & 2 & 16.7 & 12 & 24 \\
\hline & Every day & 2 & 16.7 & 8 & 30.7 & 4 & 33.3 & 14 & 28 \\
\hline & Several times a day & 0 & 0 & 0 & 0 & 0 & 0 & 0 & 0 \\
\hline & $\chi^{2}, p$ & \multicolumn{8}{|c|}{$5.61,0.691$} \\
\hline
\end{tabular}


Table 8. Cont.

\begin{tabular}{|c|c|c|c|c|c|c|c|c|c|}
\hline \multirow[t]{2}{*}{ Products } & \multirow[t]{2}{*}{ Frequency of consumption } & \multicolumn{2}{|c|}{ Underweight } & \multicolumn{2}{|c|}{ Normal BMI } & \multicolumn{2}{|c|}{ Overweight } & \multicolumn{2}{|c|}{ Total } \\
\hline & & $N$ & $\%$ & $N$ & $\%$ & $N$ & $\%$ & $N$ & $\%$ \\
\hline \multirow{7}{*}{$\begin{array}{l}\text { Vegetable } \\
\text { fats }\end{array}$} & Never or almost never & 1 & 8.3 & 3 & 11.5 & 2 & 16.7 & 6 & 12 \\
\hline & Once a month or less frequently & 0 & 0 & 3 & 11.5 & 0 & 0 & 3 & 6 \\
\hline & Several times a month & 4 & 33.4 & 3 & 11.5 & 3 & 25 & 10 & 20 \\
\hline & Several times a week & 6 & 50 & 8 & 30.8 & 6 & 50 & 20 & 40 \\
\hline & Every day & 1 & 8.3 & 9 & 34.7 & 1 & 8.3 & 11 & 22 \\
\hline & Several times a day & 0 & 0 & 0 & 0 & 0 & 0 & 0 & 0 \\
\hline & $\chi^{2}, p$ & \multicolumn{8}{|c|}{$10.35,0.241$} \\
\hline \multirow{7}{*}{$\begin{array}{l}\text { Cereal } \\
\text { products }\end{array}$} & Never or almost never & 0 & 0 & 0 & 0 & 0 & 0 & 0 & 0 \\
\hline & Once a month or less frequently & 0 & 0 & 1 & 3.9 & 0 & 0 & 1 & 2 \\
\hline & Several times a month & 2 & 16.7 & 2 & 7.7 & 1 & 8.3 & 5 & 10 \\
\hline & Several times a week & 4 & 33.3 & 9 & 34.5 & 6 & 50 & 19 & 38 \\
\hline & Every day & 6 & 50 & 13 & 50 & 5 & 41.7 & 24 & 48 \\
\hline & Several times a day & 0 & 0 & 1 & 3.9 & 0 & 0 & 1 & 2 \\
\hline & $\chi^{2}, p$ & \multicolumn{8}{|c|}{$3.29,0.915$} \\
\hline \multirow[t]{7}{*}{ Sweets } & Never or almost never & 4 & 33.4 & 8 & 30.8 & 2 & 16.7 & 14 & 28 \\
\hline & Once a month or less frequently & 1 & 8.3 & 4 & 15.3 & 1 & 8.3 & 6 & 12 \\
\hline & Several times a month & 3 & 25 & 8 & 30.8 & 4 & 33.3 & 15 & 30 \\
\hline & Several times a week & 3 & 25 & 5 & 19.2 & 5 & 41.7 & 13 & 26 \\
\hline & Every day & 1 & 8.3 & 1 & 3.9 & 0 & 0 & 2 & 4 \\
\hline & Several times a day & 0 & 0 & 0 & 0 & 0 & 0 & 0 & 0 \\
\hline & $\chi^{2}, p$ & \multicolumn{8}{|c|}{$4.05,0.853$} \\
\hline
\end{tabular}

dicated a medical doctor or dietitian as the source of their knowledge about nutrition. Ten per cent learned about nutrition from books, $4 \%$ from friends, and $2 \%$ from TV. The other parents of the children gained information about nutrition from their own experience, from observation of the child, or were guided by intuition.

\section{Discussion}

Analysis of the nutritional status of children with DS showed that only $52 \%$ of them had a normal body mass. Overweight and obesity was noted in $24 \%$ of respondents. The prevalence of overweight and obesity among preschool children in European countries ranges from $10.0 \%$ to $20.6 \%$ [19]. In the work of Roszko-Kirpsza et al., $63.3 \%$ of respondents were characterised by a normal nutritional status, whereas $24 \%$ of children with DS and $12.5 \%$ of children without DS were overweight and obese [20]. Higher rates of overweight and obesity among children and adolescents with DS have also been observed by many other authors $[4,21]$.

Dietary inclinations that contribute to the shaping of eating patterns and habits are influenced by the way the child is fed in the first period of life. KoziołKozakowska et al. observed more beneficial nutritional behaviour among breast-fed children [22]. Kowal et al., however, noticed that an overly long breastfeeding period may cause the appearance of overweight and obesity among preschool children [23]. Among the examined children with DS, $40 \%$ were breastfed until 6 months of age and $22 \%$ in the period from 6 to 12 months. However, there was no relationship between the way of feeding children with DS in the first year of life and their BMI in preschool age.

Over $80 \%$ of the children with DS had congenital malformations and diseases. Some parents also declared cow's milk protein allergy, lactose intolerance, or celiac disease. In the examined children, a re- 
lationship was observed between the occurrence of overweight and obesity and hypothyroidism. In the literature review, Bertapelli et al. suggested that hypothyroidism may be related to the BMI of children with DS [4].

Fat accumulation leads to dysfunction of the hypothalamic-pituitary-thyroid axis and to changes in thyroid function. In obese people, a higher level of thyroid-stimulating hormone (TSH) is often observed at normal concentrations of thyroid hormones. The reason for the abnormalities of these results, however, is not clear. Hypothyroidism is associated with reduced thermogenesis and metabolic rate. It is suggested that a high level of leptin may play an important role in this case [24-26].

In another study, however, overweight and obesity appeared more often in children who did not have coexisting disorders [21].

Children with DS often suffer from diseases and intolerances, which require individual nutritional recommendations and modification of the menu. Parents of these children should, therefore, especially take care of the development of their knowledge and find appropriate sources of information. Almost half of the parents surveyed declared that their nutritional knowledge comes mainly from the Internet, and only every fourth parent gained knowledge during their visits to a doctor or dietitian. The elimination diet was administered for children with DS by every third parent (34\%). These were dairy-free, lactose-free, and gluten-free diets and diets with the restriction of easily digestible carbohydrates. Unfortunately, only in the case of some of the children did the use of elimination diets have any grounds. Every second child had gluten excluded from the diet, while only $5.9 \%$ of people had celiac disease. Almost $60 \%$ of people excluded lactose from the diet, and only half of them indicated lactose intolerance. Over $40 \%$ of parents indicated in the survey a diet with the restriction of easily digestible carbohydrates, and none of the children had diabetes. The most frequently indicated reason for the use of the elimination diet was the common knowledge about the benefits of using it. Such an attitude and unwarranted use of the elimination diet may be associated with the improper content of nutrients in the diets of the subjects. In the study by Magnesis et al., regarding diets of children with DS, numerous nutritional errors were observed, such as an increased intake of carbohydrates and calories as well as sodium, accompanied by insufficient intake of calcium, certain B vitamins, and water [27]. In other studies, a high-carbohydrate diet rich in simple carbohydrates and with a deficiency of vitamins and minerals was also observed [7, 28].

Preschool children (3-6 years) should consume 4-5 meals a day. Regularity of eating meals allows one to avoid eating between meals and can also reduce the reluctance of children to eat the main meals resulting from snacking. As many as $78 \%$ of parents of children with DS declared that their children consumed five meals a day. None of the participants of the study indicated consumption of less than four meals a day. Twenty-eight percent of the examined children snacked between meals. Most of the children snacked several times a week and several times a month. The children most often chose fruit as well as yoghurts or flavoured cheese for snacking. A small percentage of children (10\%) snacked on sweets. Sosnowska-Bielicz and Wrotniak observed snacking in $78 \%$ of children and as much as 65\% declared eating sweets [29]. In other studies, the authors also showed that a large proportion of children snacked between meals, and children most often chose sweets and confectionery [22, 30].

Nutrition and the habits of preschool children are influenced not only by parents and the home environment, but also by the preschool institution - the quality and quantity of meals the child eats in kindergarten, and whether and how the parent adjusts feeding at home to preschool meals. Eating at home should complement the preschool meals. To properly plan a child's menu, it is necessary for parents to have information about meals in the kindergarten. However, as Sadowska and Krzymuska emphasise, knowledge about the preschool menu of children is often not used by parents when preparing meals at home. As many as half of parents declared that they did not use this information [31].

Our research showed that the majority of children with DS attending kindergarten consumed two $(43.5 \%)$ or three $(30.4 \%)$ meals per day in the kindergarten. Breakfast before going to kindergarten was consumed by over $70 \%$ of children, and over $60 \%$ declared consumption of two lunches (in kindergarten and at home). Studies by other authors have shown that the largest number of children consumed four meals a day in kindergarten [32]. Breakfast before going to kindergarten was consumed by only about 30$45 \%$ of children, which, as the authors suggest, may result from the belief that the child receives this meal in kindergarten.

According to the current pyramid of nutrition and physical activity, the basis of nutrition should be vegetables and fruits. In children with DS, the intake of vegetables and fruits was observed to be too low. Over $60 \%$ of the children consumed both fruit and vegetables 1-2 times a day. Almost 20\% declared consumption of these products only a few times a week. It is worrying that there were responses that showed fruit and vegetable intake several times a month and never or almost never.

Insufficient intake of vegetables and fruit by preschool children without DS with higher intake of fruit has been noted by other authors as well [32-34].

Roszko-Kirpsza et al. also analysed the impact of the amount of fruit and vegetables consumed on the nutritional status of children. As in this study, there was no significant relationship between vegetable 
and fruit intake and nutritional status (BMI) of children [20].

Children with DS usually consumed meat and meat products several times a week $(60 \%)$ or daily (34\%). Other authors showed a much higher intake of these products by children without DS. In the work of Newerli-Guz and Kulwikowska, none of the children consumed meat and meat products less often than once a day, and $40 \%$ consumed these products two or more times a day [34]. Similar results were also obtained by Roszko-Kirpsza et al. [20].

There was too little fish intake in children with DS. The largest group (62\%) consumed fish several times a month. There were also answers indicating a lack of fish consumption (8\%) and fish consumption only once a month or less frequently (12\%). Fish consumption by preschool children without DS was at a similar, excessively low level [20,34].

Consumption of milk and dairy products in children with DS was found to be too low. Only $32 \%$ of children consumed products from this group every day, and $24 \%$ several times a week. As many as 30\% of children did not consume dairy products, which could have been related to the intolerances described above or the conviction of beneficial effects of dairyfree, lactose-free diets. In the studies that describe diets of children without DS, the consumption of milk and milk products was higher [34]. A small percentage of the examined children did not consume these products or consumed them less frequently than once a day $[20,30,32,34,35]$.

The examined children with DS consumed few eggs. Most children consumed them several times a month $(44 \%)$ or several times a week (34\%). Some parents even declared that their children did not eat eggs at all. Insufficient egg consumption was also reported by other authors analysing preschool food rations $[31,36]$.

Almost every fourth child (24\%) did not consume animal fats. The same number of children consumed these products several times a week, and a similar number every day. The largest number of children with DS consumed vegetable fats several times a week $(40 \%)$ and daily (22\%). It is worrying that up to $12 \%$ of children never or almost never consumed vegetable fats. According to Myszkowska-Ryciak and Harton, there were too few animal and vegetable fats in preschool meals [36]. Sadowska and Krzymuska, however, in their work described excessive consumption of animal and vegetable fats [31].

Only nearly every second child consumed cereal products on a daily basis (48\%). Almost all other respondents indicated a smaller intake of cereal products, which could be related to the gluten-free diet. Too small portions of bread, flour, groats, pasta, cereals, and other cereal products in comparison with model food rations were also described by other authors $[31,36]$.
The parents of children with DS declared that their children ate sweets only a few times a week $(26 \%)$ or several times a month (30\%). Forty per cent of children consumed sweets less often, of which $28 \%$ indicated the answer never or almost never. Such behaviour may have resulted from preventive actions of parents who are aware of the risk of developing overweight and obesity and the health consequences associated with them. Other authors who conducted studies of children without DS, showed that the results for the consumption of sweets were much less favourable. Children ate sweets several times a week, every day, or even several times a day [29, 30, 32, 34]. Magenis et al., however, showed high carbohydrate intake among children with DS [27].

Proper diet is supplemented with proper fluid intake. Children aged 4-6 years should drink $1600 \mathrm{ml}$ of water per day [37].

Children with DS most often drank water (44\%) and fruit juices (36\%), and a small percentage of them drank tea. Among children without DS, a similar distribution of consumption of fruit juices (40\%) and water $(40 \%)$ was observed [29]. Harton et al., however, observed the highest consumption of tea (37\%) and water (34\%). Juices were consumed by fewer children (20\%) [30].

The results of this study show that the nutrition status of children with DS could be affected by hypothyroidism, a high number of meals consumed by children in kindergarten, eating two lunches (in kindergarten and at home), and eating between meals. The lack of dependence between the frequency of consumption of certain product groups and the BMI of the examined children may be due to the fact that the size of the portions consumed and the intake of calories [38], which were not analysed in the present study, had a greater impact on their body weight. The limitation of the work is also the lack of data on the physical activity of the examined children, which could have a significant impact on the formation of their BMI.

\section{Conclusions}

In children with Down syndrome at preschool age, a number of nutritional errors are made resulting in disorders in their nutritional status. The high incidence of excess body mass in children with DS may be associated with eating more meals in the kindergarten in comparison with other children, including eating two lunches (in kindergarten and at home) and eating between meals. In addition, hypothyroidism was significantly more common among children with overweight and obesity, which is also a factor that increases the risk of excess body weight. We found in the study group frequent, unjustified use of elimination diets, resulting from parents' conviction about their beneficial effects on the health of a child with 
DS. The results obtained indicate the necessity of introducing nutritional education that mainly includes kindergarten employees responsible for nutrition as well as parents and legal guardians of children with Down syndrome.

\section{Acknowledgments}

The project is supported under the program of the Minister of Science and Higher Education under the name "Regional Initiative of Excellence" in 20192022, project number: 024/RID/2018/19, financing amount: 11,999,000 PLN.

\section{Conflict of interest}

The authors declare no conflict of interest.

\section{References}

1. de Graaf G, Vis JC, Haveman M, van Hove G, de Graf EAB, Tijssen JGP, Mulder BJM. Assessment of prevalence of persons with Down syndrome: a theory-based demographic model. J Appl Res Intellect 2011; 24: 247-262.

2. Presson AP, Partyka G, Jensen KM, Devine OJ, Rasmussen SA, McCabe LL, McCabe ER. Current estimate of Down Syndrome populationprevalence in the United States. J Pediatr 2013; 163: 1163-1168

3. Mazurek D, Wyka J. Down syndrome - genetic and nutritional aspects of accompanying disorders. Rocz Państw Zakł Hig 2015; 66: 189-194.

4. Bertapelli F, Pitetti K, Agiovlasitis S, Guerra-Juniorb G. Overweight and obesity in children and adolescents with Down syndrome - prevalence, determinants, consequences, and interventions: a literature review. Res Dev Disabil 2016; 57: 181-192.

5. Ziegler J, Spivack E. Nutritional and dental issues in patients with intellectual and developmental disabilities. J Am Dent Assoc 2018; 149: 317-321.

6. Smarkandy MM, Mohamed BA, Al-Hamdan AA. Nutritional assessment and obesity in Down syndrome children and their siblings in Saudi Arabia. Saudi Med J 2012; 33: 1216-1221.

7. AbdAllah AM, Raffa S, Alaidaroos T, Obaid R, Abuznada J. Nutritional status of some children and adolescents with Down syndrome in Jeddah. Life Science J 2013; 10: 13101318

8. Kuś A. Ocena rozwoju fizycznego dzieci z zespołem Downa w wieku od 3 do 18 lat. Doctor's thesis AWF Wrocław 2002.

9. Kuś A, Sadowska L, Mysłek M. Usprawnianie korekcyjne dzieci i młodzieży z zespołem Downa w świetle dysharmonii rozwoju somatycznego. Postęp Reh 2002; 16: 65-76.

10. Basil JS, Santoro SL, Martin LJ, WusikHealy K, Chini BA, Saal HM. Retrospective study of obesity in children with Down syndrome. J Pediatr 2016; 173: 143-148.

11. Adelekan T, Magge S, Shults J. Lipid profiles of children with Down syndrome compared with their siblings. Pediatrics 2012; 129: 1382-1387.

12. Goluch-Koniuszy Z, Kunowski M. Glycemic index and glycemic load of diets in children and young people with Down's syndrome. Acta Sci Pol Technol Aliment 2013; 12: 181-194.
13. Polfuss M, Simpson P, Greenley RN, Zhang L, Sawin KJ. Parental feeding behaviors and weight-related concerns in children with special needs. West J Nurs Res 2017; 39: 1070-1093.

14. Dudek J, Chuchla M, Mazur A, Pop T. Biological risk factors obesity in schoolchildren with mental retardation from south-east Poland. Int J Obes 2006; 10: 22

15. Olchowik B, Śmigielska-Kuzia J, Otapowicz D. Stymulacja rozwoju psychoruchowego u dzieci z zespołem Downa założenia teoretyczne i praktyczne. Klin Pediatr 2010; 18: 69-74.

16. Collins K, Staples K. The role of physical activity in improving physical fitness in children with intellectual and developmental disabilities. Res Dev Disabil 2017; 69: 49-60.

17. Pitetti K, Baynard T, Agiovlasitis S. Children and adolescents with Down syndrome: physical fitness and physical activity. J Sport Health Sci 2013; 2: 47-57.

18. Kułaga Z, Litwin M, Grajda A, Gurzkowska B, ŚwiąderLeśniak A, Różdżyńska-Świątkowska A, Góźdź M, Wojtyło M i zespoły badawcze projektów OLAF i OLA. Normy rozwojowe wysokości i masy ciała, wskaźnika masy ciała, obwodu talii i ciśnienia tętniczego dzieci i młodzieży w wieku 0-18 lat. Stand Med Pediatr 2015; 12.

19. Manios Y, Androutsos O, Katsarou C, Vampouli EA, Kulaga Z, Gurzkowska B, Iotova V, Usheva N, Cardon G, Koletzko B, Moreno LA, De Bourdeaudhuij I. Prevalence and sociodemographic correlates of overweight and obesity in a large Pan-European cohort of preschool children and their families: the ToyBox study. Nutrition 2018; 55-56: 192-198.

20. Roszko-Kirpsza I, Olejnik BJ, Zalewska M, Marcinkiewicz S, Maciorkowska S. Wybrane nawyki żywieniowe a stan odżywienia dzieci i młodzieży regionu Podlasia. Probl Hig Epidemiol 2011; 92: 799-805.

21. van Gameren-Oosterom HB, van Dommelen P, Schönbeck Y, Oudesluys-Murphy AM, van Wouwe JP, Buitendijk SE. Prevalence of overweight in Dutch children with Down syndrome. Pediatrics 2012; 130: 1520-1526.

22. Kozioł-Kozakowska A, Piórecka B, Żwirska J, Jagielski P, Schlegel-Zawadzka M. Ocena sposobu żywienia dzieci w wieku przedszkolnym z regionu Krakowa z uwzględnieniem charakterystyki socjoekonomicznej. Probl Hig Epidemiol 2007; 88: 422-427.

23. Kowal M, Matusik S, Pilecki MW, Kryst Ł, Sobiecki J, Woronkowicz A. Overweight and obesity risk factors in children aged 3-7 years: a prospective study in the city of Kraków. Ann Hum Biol 2017; 44: 693-703.

24. Biondi B. Thyroid and obesity: an intriguing relationship. J Clin Endocrinol Metab 2010; 95: 3614-3617.

25. Marzullo P, Minocci A, Tagliaferri MA, Guzzaloni G, Di Blasio A, De Medici C, Aimaretti G, Liuzzi A. Investigations of thyroid hormones and antibodies in obesity: leptin levels are associated with thyroid autoimmunity independent of bioanthropometric, hormonal, and weight-related determinants. J Clin Endocrinol Metab 2010; 95: 3965-3972.

26. Sanyal D. Raychaudhuri M. Hypothyroidism and obesity: an intriguing link. Indian J Endocrinol Metab 2016; 20: 554-557.

27. Magenis ML, Machado AG, Bongiolo AM, da Silva MA, Castro K, Schweigert Perry ID. Dietary practices of children and adolescents with Down syndrome. J Intellect Disabil 2018; 22: 2. 
28. Soler Marin A, Xandri Graupera JM. Nutritional status of intellectual disabled person with Down syndrome. Nutr J 2011; 26: 1059-1066.

29. Sosnowska-Bielicz E, Wrótniak J. Nawyki żywieniowe a otyłość dzieci w wieku przedszkolnym i szkolnym. Lubelski Rocznik Pedagogiczny 2013; 32.

30. Harton A, Guzewska P, Myszkowska-Ryciak J, Gajewska D. Nawyki żywieniowe sprzyjające otyłości prostej u dzieci w wieku przedszkolnym - badanie pilotażowe. In: Znaczenie racjonalnego żywienia w edukacji zdrowotnej. Wolska-Adamczyk A (ed.), WSIiZ, Warsaw 2015; 107-116.

31. Sadowska J, Krzymuska A. Ocena uzupełnienia przedszkolnej racji pokarmowej przez rodziców u dzieci w wieku przedszkolnym. Bromatol Chem Toksyk 2010; 43: 203211.

32. Stankiewicz M, Pęgiel-Kamrat J, Zarzeczna-Baran M, Jankowski M, Pieszko Klejnowska M, Łysiak-Szydłowska W. Styl żywienia dzieci przedszkolnych $\mathrm{w}$ opinii ich rodziców. Probl Hig Epidemiol 2006; 87: 273-277.

33. Harton A, Florczak J, Myszkowska-Ryciak J, Gajewska D. Spożycie warzyw i owoców przez dzieci w wieku przedszkolnym. Probl Hig Epidemiol 2015; 96: 732-736.

34. Newerli-Guz J, Kulwikowska K. Zachowania żywieniowe i preferencje dzieci w wieku przedszkolnym. Zeszyty Naukowe Akademii Morskiej w Gdyni 2014; 86: 80-89.

35. Kostecka M. The influence of preschool children's diets on the risk of lifestyle diseases. A pilot study. Rocz Panstw Zakl Hig 2018; 69:139-145.

36. Myszkowska-Ryciak J, Harton A. Ocena realizacji norm i zaleceń żywieniowych w wybranych placówkach przedszkolnych z terenu Poznania. Probl Hig Epidemiol 2018; 99: 7-11.

37. Jarosz M, Szponar L, Rychlik E, Wierzejska R. Woda i elektrolity. In: Normy żywienia dla populacji polskiej - nowelizacja. Jarosz M (ed.). IŻŻ, Warsaw 2012; 143-153.

38. Kling SM, Roe LS, Keller KL, Rolls BJ. Double trouble: portion size and energy density combine to increase preschool children's lunch intake. Physiol Behav 2016; 162: $18-26$.

\section{Address for correspondence:}

\section{Anna Wrzochal}

Doctoral Studies

Faculty of Medicine and Health Sciences

Jan Kochanowski University

al. IX Wieków Kielc 19 A, 25-317 Kielce, Poland

Phone: +48 725635547

E-mail: annawrzochal.dietetyk@gmail.com 